\title{
PERIODONTAL MICROSURGERY AND MICROSURGICAL INSTRUMENTATION: A REVIEW
}

\author{
Kawaldeep Kaur Kang ${ }^{1}$, Deepak Grover ${ }^{2}$, Viniti Goel ${ }^{3}$, Sumit Kaushal', Gurpreet Kaur ${ }^{5}$ \\ ${ }^{1}$ PG Student, Department of Periodontology, National Dental College and Hospital, Punjab, India \\ ${ }^{2,3,4,5}$ Reader, Department of Periodontology, National Dental College and Hospital, Punjab, India
}

Corresponding Author: Kawaldeep Kaur Kang E-mail: Kaur_kawal@live.com Received: $1^{\text {st }}$ May 2016 Accepted: $16^{\text {th }}$ August 2016

Online: $11^{\text {th }}$ September 2016

\begin{abstract}
Increasing surgical refinement of procedures to meet both biologic and esthetic demands of patients is seen in today's periodontal practice. For these new technologies, instruments, and surgical techniques are necessary. Technical skills of the clinician are challenged by the limit of range of visual acuity. Periodontal microsurgery improves the outcome of basic periodontal surgical procedures by enhancing normal vision through magnification along with favorable lighting system. It gives enhanced outcomes not possible with traditional macrosurgery in terms of passive wound closure and reduced tissue trauma. The purpose of this review is to provide brief knowledge of periodontal microsurgery: the role of magnification, microsurgical instrumentation and applications of microsurgery.
\end{abstract}

Keywords: Magnification, Microsurgery, Microsurgical Instruments

\section{INTRODUCTION}

Microsurgery refers to a surgical procedure performed under a microscope. In 1980, microsurgery was described by Serafin as a methodology, a modification and refinement of existing surgical techniques using magnification to improve visualization, with applications to all specialities. ${ }^{1}$

\section{HISTORY}

Dentistry has borrowed microsurgery from medical science. Carl Nylen (1921), father of microsurgery, used surgical operating microscope for the treatment of otosclerotic deafness. ${ }^{2}$ Apotheker and Jako are given the credit to first introduce the microscope to dentistry in 1978. In periodontics, it was introduced by Shanelec and Tibbetts who presented a continuing education course on periodontal microsurgery at the annual meeting of the American Academy of Periodontology in $1993 .{ }^{3}$

\section{PRINCIPLES OF MICROSURGERY}

Major principles of microsurgery include improvement of motor skills, an emphasis on passive wound closure with exact primary apposition of the wound edge and, the application of microsurgical instrumentation and suturing to reduce tissue trauma. ${ }^{4}$

To improve motor skills a microsurgeon should have minimal tremors, a relaxed state of mind, good body comfort and posture, a wellsupported hand, and a stable instrumentholding position. The surgeon must be seated upright with the legs extending 
forward and with both feet flat on the floor. If the patient's head is assumed in the 12 o'clock position in front of and perpendicular to microsurgeon's chest, the most precise rotary suturing movement for a righthanded person is from the 2 o'clock to the 7 o'clock position, while for left-handed people it is from the 10 o'clock to the 4 o'clock position.

The wrist should be stabilized by resting on a flat surface, angled in a dorsiflection position at approximately 20 degrees. By doing so more accurate, finely controlled finger movements can be accomplished as the muscle tremor is reduced.

The most commonly used precision grip in microsurgery is the pen grip or internal precision grip, which gives greater stability than any other hand grip. ${ }^{5}$ In the three-digit grip, an instrument is held exactly as a pen is held when writing. The thumb and index and middle fingers are used as a tripod. The forearm should be slightly supine, positioning the knuckles away from clinician, so that the ulnar border of his/her hand, wrist, and the elbow are all well supported, allowing the weight of the hand to be on the ulnar border.

The thumb and index finger are arranged on the instrument into contact with the underlying steady middle finger. When an instrument is held with the internal precision grip, the instrument can be opened and closed with very fine control and fatigue is resisted.

\section{MICROSURGICALTRIAD}

The concept of microsurgery is based on three important elements which form the microsurgical triad that includes magnification, illumination and instruments. ${ }^{6}$ Without any one of these, microsurgery is not possible.

\section{1) MAGNIFICATION}

Visual acuity is the ability to perceive two closely lying objects separately. Visualization of fine details can also be enhanced by increasing the image size of the object.
Magnification systems:

A variety of simple and complex magnifications are available to dentists, ranging from simple loupes to prism telescopic loupes and surgical microscopes. Each magnification system has its own specific advantages and limitations.

Dental loupes are the most common system of optical magnification. They are fundamentally dual monocular telescopes with side-by-side lenses convergent to focus on the operative field. ${ }^{7}$ The magnified image formed has stereoscopic properties by virtue of their convergence. A convergent lens optical system is called a Keplerian optical system. Although being less expensive and cumbersome, dental loupes are widely used but they have disadvantages compared with the microscope. The clinician's eyes must converge to view the operative field which can result in eyestrain, fatigue, and even pathologic vision changes; especially after prolonged use. ${ }^{6}$ Three types of Keplerian loupes are typically used in periodontics: simple or single-element loupes, compound loupes, and prism telescopic loupes.(Table 1)

Table 1: Comparison of dental loupes

\begin{tabular}{|c|c|c|}
\hline $\begin{array}{l}\text { Simple } \\
\text { Loupes }\end{array}$ & $\begin{array}{l}\text { Compound } \\
\text { Loupes }\end{array}$ & $\begin{array}{l}\text { Prism Telescopic } \\
\text { Loupes }\end{array}$ \\
\hline $\begin{array}{l}\text { Pair of single } \\
\text { meniscus } \\
\text { lenses }\end{array}$ & $\begin{array}{l}\text { multiple lenses } \\
\text { with intervening } \\
\text { air spaces to gain } \\
\text { additional } \\
\text { refracting surfaces }\end{array}$ & $\begin{array}{l}\text { Schmidt or "rooftop" } \\
\text { prisms to lengthen the } \\
\text { light path through a } \\
\text { series of switch back } \\
\text { mirrors between the } \\
\text { lenses }\end{array}$ \\
\hline $\begin{array}{l}\text { Magnification } \\
\text { can only } \\
\text { increase by } \\
\text { increasing } \\
\text { lens diameter } \\
\text { and thickness }\end{array}$ & $\begin{array}{l}\text { Magnification can } \\
\text { be increased by } \\
\text { lengthening the } \\
\text { distance between } \\
\text { lenses, without } \\
\text { excessive increase } \\
\text { in size or weight. }\end{array}$ & \\
\hline $\begin{array}{l}\text { Greatly } \\
\text { affected by } \\
\text { spherical and } \\
\text { chromatic } \\
\text { aberration }\end{array}$ & Can be achromatic & Achromatic \\
\hline $\begin{array}{l}\text { Impractical } \\
\text { for } \\
\text { magnification } \\
\text { beyond } 1.5 \mathrm{X}\end{array}$ & $\begin{array}{l}\text { Inefficient at } \\
\text { magnifications } \\
\text { above } 3 X \text {. }\end{array}$ & $\begin{array}{l}\text { better magnification, } \\
\text { wider depths of field, } \\
\text { longer working } \\
\text { distances, and larger } \\
\text { fields of view }\end{array}$ \\
\hline
\end{tabular}




\section{SURGICAL MICROSCOPE}

It is a complicating system of lenses that allows binocular viewing at magnification of approximately $4 \mathrm{X}$ to $40 \mathrm{X}^{7}$

\section{Basic Principles of the Surgical Microscope}

In the binocular concept, the length of the telescope becomes condensed by the use of prisms. The components of microscope are the basic stereo microscope, the binocular head, and the objective lens. This microscope, however, contains two additional elements: a magnification changer and an illuminator which beams the light in through the objective lens. Operating microscopes combine the magnification of loupes with a magnification changer and a binocular viewing system. This type of illumination is desirable because the line of illumination is very close to the viewer's line of vision. Therefore, the surgical field will be illuminated and free of shadows.

\section{Advantages and Disadvantages of the Surgical Microscope $^{8}$}

\section{Advantages}

\section{Postural}

- Less discomfort to the back and neck of the clinician.

- Less tiredness of eyes, as constant adjustments are avoided.

\section{Procedural}

- Atraumatic tissue management.

- Accurate primary wound closure.

- Increased diagnostic skills.

- Minimally invasive.

- Improved cosmetic results.

- Increased surgical quality.

- Increased effectiveness of root debridement results in greater predictability of a) Regeneration procedures, b) Cosmetic procedures.

- Improved documentation e.g. video, slide, digital.

3. Pschological

- Less patient anxiety.

- Increased personal, professional satisfaction when improved quality of surgical treatments is seen.

\section{Disadvantages}

1. Educational requirements.

- Surgical technique

- Understanding of optics

2. Long adjustment period for clinical proficiency.

3. Initial increased surgical time.

4. High patient cost.

5. Limited surgical access.

2) ILLUMINATION: Most of the manufacturers offer collateral lighting systems which are helpful, particularly for higher magnification in the range of $4 \mathrm{X}$ and more.

Considerations to be made in the selection of an accessory lighting source. $^{2}$

1. Total weight, quality, and brightness of the light.

2. Ease of focusing and directing the light within the field of view.

3. Ease of transport between surgeries.

\section{3) MICROSURGICAL INSTRUMENTS (Table2)}

Using conventional instruments in microsurgery is not really an option as their size implies a larger surgical access, which goes against the whole concept of microsurgery. So microsurgical instruments are the third element of microsurgical triad.

\section{Rationale in favour of microsurgical instruments}

- As the inflammation, oedema, post- operative pain, and the healing time are increased with larger spread of the soft and hard tissues 
included in the manipulation, limiting the extent of the surgical site reduces morbidity.

- Tissues suffer more from crushing than incisions or puncture. The edginess of ophthalmic surgical blades is obtained by electrolytic process and not machined. So, the blade edges are sharper, and the surface texture of the blade is smoother, resulting in a perfect incision leading to least possible trauma. Blunt instruments crush the fragile tissues, potentially inducing necrosis, while the forceps with microscopic teeth allows the operator to delicately reposition the soft tissues.

- Risk of necrotic zones and its related aesthetics and functional consequences are more if the blood supply to the tissues handled is compromised. Certain incisions are altogether avoided using a microscope contributing to a better blood perfusion of the tissues.

For example, while harvesting a connective tissue graft from the palate, magnification makes it technically easier to proceed with a unique incision line, running parallel to the cervix of the teeth, thus avoiding releasing incisions that would deny the flap from one source of its blood supply. Likewise, immediate implant placement, combined with athickening of soft tissue with a connective tissue graft, can be done with no releasing incision if visibility is adequate using magnification. Also, the risk of scars is eliminated and revascularization of the grafts is faster.

Properties of microsurgical instruments-

- light to prevent hand fatigue;

- rigid enough to maintain proper stability;

- long enough to rest on the saddle formed by the thumb and the index finger;

- round handles to allow rotational movements;

- circular in cross section to allow for a smooth rotation movement;
- working tips of much smaller than those of regular instruments;

- non-reflective to avoid blinding the operator (especially with the high-intensity light of the microscope);

- non-magnetic;

- machined to a very high level of precision to allow a good grip on very small needle or very delicate tissue without damaging them, and still allow an easy opening-closing action.

\section{MICROSURGERY IN PERIODONTICS}

Clinical expertise beyond the range of visual acuity is needed in periodontal plastic surgery, guided tissue regeneration, crown lengthening, ridge augmentation, implant placement etc. So microsurgery is very important in periodontics.

Esthetic Surgical Procedures- Periodontal plastic surgery is "technique-sensitive" and more demanding than other periodontal procedures. Microsurgery has wide implications including the rotational, free gingival, double papilla, and the sub-epithelial connective tissue grafts for the coverage since it causes minimal trauma and enhances the wound healing process. ${ }^{12}$ The combination of small microsurgical instruments and delicate surgical techniques allow for extremely fine, crisp and accurate incisions, gentle tissue handling, and precise suturing.

Root coverage- Accurate diagnosis with microsurgical techniques makes complete root coverage extremely predictable in Class I and Class II marginal tissue recessions. Partial root coverage results achieved in Class III \& Class IV marginal recession with conventional surgery can also be greatly enhanced through the use of microsurgery. According to studies, the use of microsurgical technique depicted a greater increase in width of keratinized tissue and thickness of keratinized tissue as compared to the macro- surgical techniques performed. ${ }^{13-17}$ 
Table 2: Different microsurgical instruments

A basic set of periodontal surgical instruments includes ${ }^{9,10,11}$

\begin{tabular}{|c|c|c|c|}
\hline NAME & TYPE & SUBTYPES & ADVANTAGES \\
\hline Knives & $\begin{array}{l}\text { a.Blade breaker knife } \\
\text { b.Crescent knife } \\
\text { c.Minicrescent knives } \\
\text { d.Spoon knife } \\
\text { e.Lamellar knife }\end{array}$ & & $\begin{array}{ll}- & \text { Extremely sharp } \\
\text { - } & \text { Small size } \\
\text { Etched rather than ground- produce } \\
\text { more precise wound edge }\end{array}$ \\
\hline $\begin{array}{l}\text { Microsurgical } \\
\text { periodontal } \\
\text { knives }\end{array}$ & $\begin{array}{l}\text { a.Orban periodontal } \\
\text { knife(KO1/2MBH) } \\
\text { b.Kramer-Nevins gingivectomy } \\
\text { knife(KKN7MBH) }\end{array}$ & & - $\quad$ Very sharp \\
\hline $\begin{array}{l}\text { Microsurgical } \\
\text { blades }\end{array}$ & $\begin{array}{l}\text { a.Ophthalmic blade } \\
\text { b.Blade no } 15 \\
\text { c.Blade no } 12 \\
\text { d.Blade no } 390 \\
\text { e.Blade no } 390 \text { c }\end{array}$ & $\begin{array}{l}\text { No. } 15 \mathrm{c} \\
\text { No. } 12 \mathrm{~d}\end{array}$ & $\begin{array}{l}\text { - Curved in a 'J' shape } \\
\text { - Can be run under the papilla to } \\
\text { separate it from the underlying bone } \\
\text { support, progressing in the narrow } \\
\text { space of the dental embrasure } \\
\text { - Fine incision }\end{array}$ \\
\hline $\begin{array}{l}\text { Microsurgical } \\
\text { periosteal elevator }\end{array}$ & $\begin{array}{l}\text { a.Periosteal Schlee PPSCHLEE } \\
\text { Handle } 6 \\
\text { b.Prichard periosteal (PPRMBH) } \\
\text { c.Hourigan periosteal } \\
\text { (PH2MBHKD) }\end{array}$ & & - $\quad$ Precise undermining and release of flap \\
\hline $\begin{array}{l}\text { Microsurgical } \\
\text { periodontal } \\
\text { retractors }\end{array}$ & KP Retractors & $\begin{array}{l}\text { a.KP } 1 \text { Retractor } \\
\text { b. KP } 2 \text { Retractor } \\
\text { c. KP } 3 \text { Retactor }\end{array}$ & $\begin{array}{l}\text { Wider and thinner serrated working ends } \\
\text { provide } \\
\text { - better anchorage on bone and } \\
\text { - prevent accidental slipping }\end{array}$ \\
\hline $\begin{array}{l}\text { Microsurgical } \\
\text { tissue foreceps }\end{array}$ & $\begin{array}{l}\text { a.Microsurgical anatomic tissue } \\
\text { pliers TPASTMBH } \\
\text { b.Microtissue foreceps } 180\end{array}$ & & $\begin{array}{l}\text { Handle minute tissues without } \\
\text { damaging them }\end{array}$ \\
\hline $\begin{array}{l}\text { Microsurgical } \\
\text { periodontal } \\
\text { chisels }\end{array}$ & $\begin{array}{l}\text { a.Rhodes chisel } \\
\text { b.Wedelstaedt chisel } \\
\text { c.Fedi chisel }\end{array}$ & & - $\quad$ Precise bone cutting \\
\hline $\begin{array}{l}\text { Microsurgical } \\
\text { periodontal } \\
\text { curettes }\end{array}$ & Langer curettes & $\begin{array}{l}\text { a. SL1/2RMBH } \\
\text { b. SL3/4RMBH } \\
\text { c. SL5/6RMBH }\end{array}$ & \\
\hline $\begin{array}{l}\text { Microsurgical } \\
\text { periodontal } \\
\text { needle holder }\end{array}$ & $\begin{array}{l}\text { Microneedle holder } \\
\text { Schlee(NHSLSCHLEE) }\end{array}$ & & $\begin{array}{l}\text { - } \quad \text { Lock to firmly secure the needle } \\
\text { - Can be guided through coarse gingival } \\
\text { tissue with controlled grip pressure } \\
\text { - Slender shape allows them to reach far } \\
\text { into interproximal areas }\end{array}$ \\
\hline $\begin{array}{l}\text { Microsurgical } \\
\text { suturing foreceps }\end{array}$ & & & $\begin{array}{l}\text { - Can easily grab microsutures which can } \\
\text { be torn with usual surgical suturing } \\
\text { foreceps }\end{array}$ \\
\hline Microscissors & $\begin{array}{l}\text { a.Micro-vannas tissue scissors } \\
\text { b.Goldman-Fox scissors } \\
\text { c.Ligature scissors FD252R }\end{array}$ & & $\begin{array}{l}\text { - Smooth cutting of fine and coarse } \\
\text { tissues } \\
\text { - } \text { Reduced tissue trauma }\end{array}$ \\
\hline Microsutures & $6-0$ to $10-0$ & $\begin{array}{l}\text { Vicryl polyglactin }(7-0 \text { to } \\
10-0) \\
\text { Ethilon polyamide }(7-0,9-0)) \\
\text { Prolene polypropylene }(8- \\
0,10-0))\end{array}$ & $\begin{array}{l}\text { - } \text { Better wound closure } \\
\text { Minimizing gaps or voids at the wound, } \\
\text { rapid healing with less post-operative } \\
\text { in? ammation, pain and risk of scar } \\
\text { formation. }\end{array}$ \\
\hline $\begin{array}{l}\text { Microsurgical } \\
\text { needles }\end{array}$ & $\begin{array}{l}\text { a.Reverse cutting needles with } \\
\text { precision tips } \\
\text { b.Spatula needles with microtips }\end{array}$ & & $\begin{array}{l}\text { Shallow needle track and precise needle } \\
\text { point allows extremely accurate apposition } \\
\text { and closure of flap }\end{array}$ \\
\hline
\end{tabular}


Papilla reconstruction- Apart from the various root coverage procedures performed other mucogingival surgeries like papilla reconstructions and ridge augmentation around natural teeth and implants can also be carried out.

Implant surgery- Microsurgery has proved its potential in implant surgeries. It has established itself in implant site development and implant placement using both the flap and flapless techniques.

Sinus lift procedures - Sinus lift procedures using the microsurgical approach are also gaining recognition. The periodontal endoscope allows for subgingival visualization of the root surface at magnifications of $24 \mathrm{x}$ to $48 \mathrm{x}$. This is accomplished through a $0.99 \mathrm{~mm}$ fiber optic bundle that is a combination of a 10,000pixel capture bundle surrounded by multiple illumination fibers. This fiber is delivered to the gingival margin coupled into an instrument called an "explorer." A single use sterile sheath isolates the fiber so it can be used repeatedly. The captured image is relayed to a screen so that the user can see "real time" video of the highly magnified environment (approximately $3 \mathrm{~mm}$ on screen at a time)

Root Surface Conditioning- Since root surface preparation addresses how the soft tissue attaches to the root of the tooth in root coverage surgery, it is of the utmost importance. In an attempt to get new periodontal ligament attachment of a graft to the tooth with new cementum and Sharpey's fibers, several methods of root preparation have been suggested including mechanical root preparation, chemical root preparation, and biologic root preparation. The outcomes of some methods are based on histologic evidence and others on empirical observation, but all are important for successful root coverage.

\section{REFERENCES}

1. Seraffin D. Microsuergery past present and future. Plast Reconstruct Surg 1980:66:781-785.

2. Shah C, Shah S, Modi D. Microsurgery in periodonticsRevisited. Journal of research and advancement in dentistry
2012; 1(3).

3. Shanelec DA, Tibetts LS. A perspective on the future of periodontal microsurgery. Periodontol 2000 1996;11:58-64.

4. Tibbets LS, Shanelec D.P. Principles And Practice Of Periodontal Microsurgery Int J Microdent 2009;1:13-24.

5. Barraquer JI. The history of microsurgery in ocular surgery. J Microsurg 1980;11:288-299.

6. Belcher JM. A perspective on periodontal microsurgery. Int $\mathrm{J}$ Periodontics Restorative Dent 2001;21:191-196.

7. Burkhardt R, Lang NP. 5th ed. Vol 2. Blackwell Munksgaard;2008 Jan lindhe's Clinical periodontology \& implant dentistry,pg-1029-1043.

8. Calderon GM, Lagares DT, Vazquez CC, Gargallo JU, Perez LG. The application of microscopic surgery in dentistry. Med Oral Patol Cir Bucal 2007;12:1311-316.

9. Herzeler MB. Hu-Friedy's Periodontal Microsurgical Instrument set

10. Syngcuk Kim. 1st ed. W.B. Saunders Company; 2001. Colour Atlas Of Microsurgery in Endodontics.

11. Klokkevold PR, Caranza FA, Takei H. 10th ed. Newyork W B Saunders;2010 Carranza's Clinical Periodontology.

12. Tibbetts LS, Shanelec D. Periodontal microsurgery. Dent Clin North Am 1998;42:339-59.

13. Burkhardt R, Lang NP. Coverage of localized gingival recessions: Comparison of micro- and macro surgical techniques. J Clin Periodontol 2005; 32:287-93.

14. Cortellini P, Tonetti MS. A minimally invasive surgical technique with an enamel matrix derivative in the regenerative treatment of intra-bony defects: A novel approach to limit morbidity. J Clin Periodontol 2007;34:87-93.

15. Cortellini P, Tonetti MS. Microsurgical approach to periodontal regeneration. Initial evaluation in a case cohort. J Periodontol 2001; 72:559-69.

16. Francetti L, Del Fabbro M, Calace S, Testori T, Weinstein RL. Microsurgical treatment of gingival recession: A controlled clinical study. Int J Periodontics Restorative Dent 2005; 25:181-8.

17. Andrade PF, Grisi MF, Maracaccini AM, Fernandes PG, Reino DM, Souza SL, Comparison between micro and macrosurgical techniques for the treatment of localized gingival recessions using coronally repositioned flaps and enamel matrix derivative. J Periodontol 2010;81:1572-9.

18. Ravishankar P L, Venugopal K, Periodontal microsurgery a perspective. Periodontics 2012;1:68-72.

19. Cohen ES. 3rd ed. Hamilton: BC Decker Inc; 2007. Atlas of Cosmetic and Reconstructive Periodontal Surgery.

20. Fanibunda U, Meshram G, Warhadpande M. Evolutionary perspectives on the dental operating microscope: A macro 
revolution at the micro level. Int J Microdent 2010;2:15-19.

21. Carr GB. Microscopes in endodontics. J Calif Dent Assoc 1992;20:55-61.

22. Campbell D. Magnificaion is major aid to dentists and now microdentistry's time has come. Future Dent 1989;4:11.

23. Caplan SA. Magnification in dentistry.J Esthet Dent 1990;2:17-21.

24. Cortellini P, Tonetti MS. Microsurgical approach to periodontal regeneration. Initial evaluation in a case cohort. $\mathrm{J}$ Periodontol 2001;72:559-69.

25. Andrade PF, Grisi MF, Maracaccini AM, Fernandes PG, Reino DM, Souza SL Comparison between micro- and macrosurgical techniques for the treatment of localized gingival recessions using coronally repositioned flaps and enamel matrix derivative. J Periodontol 2010; 81:1572-9.

26. Burkhardt R, Lang NP. Coverage of localized gingival recessions: Comparison of micro- and macro surgical techniques. J Clin Periodontol 2005;32:287-93.

27. Francetti L, Del Fabbro M, Calace S, Testori T, Weinstein RL. Microsurgical treatment of gingival recession: A controlled clinical study. Int J Periodontics Restorative Dent 2005; 25:181-8.

28. Michaelides PL. Use of the operating microscope in dentistry. J Calif Dent Assoc 1996; 24:45-50.

29. Shanelec DA. Optical principles of loupes. Calif Dent Assoc J 1992;20:25-32. 